NGHIÊN CÚU

\title{
Bàn thêm về tính trái pháp luật quốc tế trong chính sách, pháp luật biển của Trung Quốc - nhìn từ góc độ các nguyên tắc cơ bản và Công ước Luật Biển năm 1982 của Liên hợp quốc
}

\author{
Nguyễn Bá Diến*, Đồng Thị Kim Thoa \\ Khoa Luật, Đại học Quốc gia Hà Nội, 144 Xuân Thủy, Cầu Giấy, Hà Nội, Việt Nam \\ Nhận ngày 05 tháng 3 năm 2017 \\ Chỉnh sửa ngày 30 tháng 05 năm 2017; Chấp nhận đăng ngày 28 tháng 6 năm 2017
}

\begin{abstract}
Tóm tắt: Bài viết trình bày khái quát và đặc điểm của chính sách, pháp luật biển Trung Quốc. Từ đó, bài viết đi đến kết luận rằng: Nội dung xuyên suốt trong chính sách, pháp luật biển của Trung Quốc là tư tưởng bá quyền và chủ nghĩa "Đại Hán", thể hiện tham vọng bành trướng trên biển; mặc dù đã sử dụng nhiều xảo thuật nhưng vẫn không thể che đậy tính trái pháp luật quốc tế cũng như sự vô trách nhiệm của quốc gia này trước cộng đồng quốc tế.
\end{abstract}

Từ khóa: Trái pháp luật, luật quốc tế, chính sách biển, pháp luật biển, Trung Quốc, nguyên tắc cơ bản, công ước luật biển.

\section{Khái quát chung về chính sách, pháp luật biển của Trung Quốc}

Trong quá trình phát triển hàng ngàn năm của lịch sử Trung Quốc, do sự khác nhau về trình độ phát triển kinh tế, chính trị, xã hội và môi trường quốc tế của các thời kỳ cùng với sự thay đổi trong quan niệm biển của người dân Trung Quốc nên chính sách, pháp luật biển của Trung Quốc cũng có sự thay đổi tương ứng.

Trong thời kỳ cổ đại và phong kiến, tâm lý canh nông và tư tưởng lục địa đã bồi dưỡng nên ý thức của văn hóa hoàng thổ của dân tộc trung Hoa "dĩ nông vi bản" (lấy nông nghiệp làm

\footnotetext{
*Tác giả liên hệ. ĐT.: 84-903426509

Email: nbadien@yahoo.com
}

gốc), hình thành khuynh hướng chính sách "trọng lục khinh hải" (coi trọng đất liền, coi nhẹ biển), theo đó, Trung Quốc đã duy trì chính sách "Cấm hải", "Bế quan tỏa cảng", hạn chế và dè dặt trong việc mở rộng giao lưu với nước ngoài, nhất là bằng con đường hàng hải (đặc biệt là dưới hai triều đại Minh, Thanh). Sau này, xuất phát từ những nguồn lợi đến từ biển nên người Trung Quốc đã có ý thức hướng ra biển và rất nỗ lực hình thành nên quan niệm biển sơ khai ban đầu. Đặc biệt, sau cuộc chiến tranh Nha Phiến, mối đe dọa đến từ vùng ven biển đã làm thức tỉnh ý thức về biển của Trung Quốc, hình thành một loạt ý tưởng về chiến lược biển, trong đó, ý tưởng của Tôn Trung Sơn là ý tưởng đặc thù và hoàn chỉnh hơn cả ${ }^{1}[1$, tr.

${ }^{1}$ Ý tưởng của Tôn Trung Sơn gồm 05 nội dung chính: Dĩ hải vi bản; hải quyền; hải phòng, hải quân và dĩ hải hưng quốc. 
248]. Tuy nhiên, chính sách biển của Trung Quốc thời kỳ này lại mang tính chất bị động. Cho đến tận thế kỷ XIX, Trung Quốc vẫn hoàn toàn không coi biển cả là một khu vực cần chinh phục và khai thác, chinh phạt và nếu có thì đều là lý do phòng thủ hơn là lý do bành trướng $[2$, tr. 285]. Xuất phát từ những quan niệm, chủ trương đó nên các văn bản thể hiện chính sách pháp luật về biển đảo của Trung Quốc trong thời kỳ này còn rất hạn chế, các văn bản đề cập đến Biển Đông phần nhiều chỉ là các quyết định/lệnh, điều lệ, công hàm, tuyên bố ${ }^{2}$.

Sau chiến tranh thế giới thứ hai, đặc biệt là sau khi chính quyền Cộng hòa Nhân dân (CHND) Trung Hoa được thành lập năm 1949, do sức ép về nguồn tài nguyên, sinh thái biển, cùng với tham vọng bành trướng, bá quyền trước sự phát triển của luật biển quốc tế hiện đại, chính sách biển của Trung Quốc đã có nhiều thay đổi mới. Nếu như trong thời kỳ lãnh đạo của Mao Trạch Đông và Đặng Tiểu Bình, Trung Quốc duy trì chính sách "phòng ngự biển gần" với phương châm "giấu mình chờ thời", "giữ ổn định", "gác tranh chấp cùng khai thác" thì , trong thời gian gần đây, đặc biệt là từ khi Tập Cận Bình trở thành Tổng bí thư kiêm Chủ tịch nước, Trung Quốc đã có một bước đi táo tợn trong chính sách pháp luật về biển đảo thông qua việc đẩy mạnh chiến lược "phòng ngự biển xa" và "hải quân viễn dương" với phương châm "chủ động gây hấn, dùng sức mạnh để giải quyết mọi tranh chấp biển đảo với các nước xung quanh" [3].

Với Trung Quốc, việc thống trị biển đảo, nhất là đối với Biển Đông và hai quần đảo Hoàng $\mathrm{Sa}$, Trường Sa nói riêng có ý nghĩa sống còn, là "bể cá vàng", là "yết hẩu", là "con đường sinh mệnh" $[4$, tr. 4$]$, là một trong những phương cách có tính quyêt định giúp quốc gia này vươn lên vị trí siêu cường quốc tế. Liên quan đến vấn đề này, các chiến lược gia Trung Quốc đã tổng kết và chỉ ra rằng biển đảo là

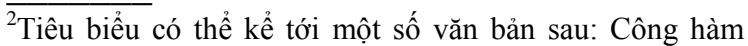
ngày 29/9/1932 từ Công sứ quán Trung Quốc tại Pháp; Bản ghi nhớ về Tình hình Đài Loan ngày 18/4/1947; Hiến pháp Trung Hoa Dân quốc 1946 có hiệu lực từ năm 1947 và sửa đổi lần cuối năm 2000.
}

"nhân tố cần thiết mang tính chất sống còn trong sự thịnh vượng lâu dài đối với quốc gia" [5, tr. 47-67], là "hòn đá tảng" trong chiến lược phát triển của Trung Quốc.

Nhằm phục vụ cho chiến lược "cường quốc biển", song hành với việc hoàn thiện cơ cấu các cơ quan quản lý nhà nước cũng như các cơ quan chấp pháp trên biển, Trung Quốc còn ban hành nhiều chính sách và quy định liên quan đến từng lĩnh vực biển đảo cụ thể. Trong đó, chính sách biển đảo của Trung Quốc được thể hiện chủ yếu thông qua các văn bản sau: Quy hoạch, Cương yếu Quy hoạch; Kế hoạch 5 năm; Sách trắng. Chính sách, chiến lược biển của Trung Quốc sau đó đã được cụ thể hóa và trở thành kim chỉ nam cho các văn bản pháp luật về biển đảo của Trung Quốc trong gần 7 thập kỷ qua với các văn bản chính sau: Hiến pháp nước CHND Trung Hoa năm 1982, sửa đồi, bổ sung năm 1988, 1993, 1999 và 2004; Tuyên bố về lãnh hải của Chính phủ nước CHND Trung Hoa năm 1958; Luật lãnh hải và vùng tiếp giáp năm 1992; Quyết định của UBTV Đại hội đại biểu nhân dân toàn quốc năm 1996 về phê chuẩn Công ước Luật biển của Liên hợp quốc (UNCLOS 1982); Tuyên bố về đường cơ sở tính chiều rộng lãnh hải CHND Trung Hoa năm 1996; Luật vùng đặc quyền kinh tế và thềm lục địa nước CHND Trung Hoa năm 1998; Luật Bảo vệ hải đảo nước CHND Trung Hoa năm 2009; Luật về Quản lý các vùng biển của nước CHND Trung Hoa năm 2001; Lệnh cấm đánh bắt cá hàng năm (từ năm 1999 đến nay); Công hàm số $C M L / 17$ và $C M L / 18$ ngày 7/5/2009 gửi Tổng thư ký Liên hợp quốc (kèm theo bản đồ "đường lưỡi bò" phi pháp) v.v...

Ngoài các văn bản thể hiện tham vọng bành trướng chủ quyền biển đảo, chính quyền Trung Quốc còn ban hành nhiều văn bản pháp quy khác như: Quyết định của UBTV Quốc hội nước CHND Trung Hoa về thành lập Tòa án Hàng hải tại các Thành phố cảng biển năm 1984; Luật Ngư nghiệp của nước CHND Trung Hoa năm 1986 (sửa đổi năm 2013); Luật Tài nguyên khoáng sản của nước CHND Trung Hoa năm 1986 (sửa đổi năm 2009); Luật Bảo vệ môi trường biển năm 1982 (sửa đồi năm 1999); Quy 
định quản lý nghiên cứu khoa học biển liên quan đến nước ngoài năm 1996; Bộ luật Hàng hải nước CHND Trung Hoa năm 1992; Luật An toàn giao thông trên biển của nước CHND Trung Hoa năm 1983; Điều lệ quản lý trị an biên phòng ven biển tỉnh Hải Nam năm 2012; Dự thảo sửa đổi Biện pháp thực hiện Luật Ngư nghiệp nước CHND Trung Hoa có hiệu lực từ $1 / 1 / 2014 \ldots$ Những văn bản pháp luật này đã thiết lập cơ sở pháp lý cho việc quản lý hoạt động biển, sử dụng quản lý các vùng biển, bảo vệ môi trường biển của nước CHND Trung Hoa v.v...

\section{2. Đặc điểm của chính sách, pháp luật biển Trung Quốc dưới góc độ pháp lý quốc tế}

Chính sách, pháp luật biển của Trung Quốc, từ góc độ luật pháp quốc tế, có những đặc điểm cơ bản như sau:

Thứ nhất, chính sách pháp luật về biển đảo của Trung Quốc từ năm 1949 đến nay đã phản ánh một cách chân xác về sự thay đổi trong nhận thức và quan niệm biển của lãnh đạo Trung Quốc và được triển khai với một chiến lược hết sức bài bản. Với tham vọng bành trướng trên biển, bằng việc ban hành hàng loạt các văn bản về biển, Trung Quốc, trên cơ sở khai thác triệt để những nội dung có lợi cho riêng mình và cố tình viện dẫn sai lệch các quy định của pháp luật quốc tế, đã xây dựng được một khung pháp lý khá toàn diện, điều chỉnh hầu khắp các hoạt động trên các vùng biển, chủ yếu từ vùng đặc quyền kinh tế và thềm lục địa cho đến các hải đảo, nhằm phục vụ cho lợi ích dân tộc hẹp hòi, sô vanh nước lớn [6].

Thứ hai, với sự phức tạp, nhiều tầng, cấp tham gia quản lý nhà nước trong các lĩnh vực, chính sách pháp luật biển của CHND Trung Hoa là sự phản ánh chân xác các quan điểm, chủ trương về yêu sách và tham vọng bành trướng trên biển của giới chức cầm quyền Trung Quốc. Các văn bản pháp luật của Trung Quốc được xây dựng nhằm tạo lập cơ sở pháp lý cho các hoạt động khai thác, sử dụng, quản lý biển, hợp thức hóa các hoạt động phi pháp của Trung Quốc trên các vùng biển (vùng biển của nước ngoài, vùng biển tranh chấp và vùng biển quốc tế) [4, tr. 37].

Thú $\boldsymbol{b a}$, nội dung quy định pháp luật biển đảo Trung Quốc có nhiều điểm trái pháp luật quốc tế, đặc biệt là so với UNCLOS 1982, xâm phạm đến quyền và lợi ích của các quốc gia khác trong đó có Việt Nam, thể hiện cụ thể ở các vấn đề: i) Quy chế pháp lý đối với đảo, quần đảo; ii) Quy định tàu quân sự nước ngoài trước khi vào lãnh hải Trung Quốc phải xin phép trước; iii) Quy định về quyền kiểm soát an ninh trong phạm vi vùng tiếp giáp lãnh hải; iv) Quy định về "quyền lợi lịch sử" trong vùng đặc quyền kinh tế và thềm lục địa của quốc gia khác; v) Quy định về lệnh cấm đánh bắt cá hàng năm mang tính đơn phương và áp đặt vô lý đối với các nước khác ở Biển Đông.

Thứ $t u$, hầu như các đạo luật về yêu sách biển của Trung Quốc đều hoặc là né tránh, hoặc loại bỏ những quy định của pháp luật quốc tế có thể gây bất lợi, ràng buộc mình; tìm mọi cách bổ sung các quy định có lợi cho riêng mình. Nhiều văn bản do Trung Quốc ban hành mang tính đơn phương, phi khoa học, trái với pháp luật quốc tế nhằm áp đặt chủ quyền, quyền chủ quyền của mình, xâm phạm nghiêm trọng chủ quyền và lợi ích hợp pháp của Việt Nam và các quốc gia hữu quan. Những văn bản này nhằm tạo cơ sở pháp lý cho việc gia tăng và mở rộng quyền kiểm soát, chiếm hữu của Trung Quốc đối với các vùng biển tranh chấp và khống chế toàn bộ Biển Đông [4, tr. 57-58].

Thứ năm, hệ thống chính sách, pháp luật Trung Quốc về Biển Đông nói chung, trực tiếp quy định về các quần đảo Hoàng $\mathrm{Sa}$, Trường $\mathrm{Sa}$ nói riêng vừa là kết quả của thực tiễn xâm chiếm và yêu sách Biển Đông của Trung Quốc, cũng vừa là cơ sở pháp lý, làm nền tảng cho việc tiếp tục hiện thực hóa, mở rộng mưu đồ bành trướng chủ quyền của quốc gia này. Mặc dù, được quan tâm từ thập niên đầu thế kỷ $\mathrm{XX}$ thời chính quyền Trung Hoa Dân Quốc, tuy nhiên, các văn bản pháp luật giữa Trung Quốc 
ngày nay (CHND Trung Hoa) và chính thể Đài Loan (Trung Hoa Dân Quốc), dẫu đều có cùng những yêu sách về Biển Đông, nhưng cũng có những điểm khác nhau nhất định trong cùng một vấn đề pháp lý về biển, đảo;

Thứ sáu, để thực thi chính sách, pháp luật biển, hiện thực hóa chiến lược bá quyền trên biển bên cạnh việc sửa đổi, bổ sung, bãi bỏ, thay thế các văn bản trước đó, Trung Quốc đã huy động tổng lực hệ thống chính trị từ trung ương đến địa phương và các các lực lượng chuyên trách, áp dụng hàng loạt các chiến thuật, chiến lược trên tất cả các lĩnh vực, kết hợp khôn khéo "chiến tranh truyền thông, chiến tranh tâm lý" bên cạnh việc dùng ngoại giao đi trước và quân sự theo sau [7, tr. 84]. Quá trình xây dựng, thực thi chính sách pháp luật biển của Trung Quốc phản ánh tính nhất quán tham vọng độc chiếm Biển Đông của Trung Quốc với sự lập trình tinh vi, bài bản trong việc mưu đồ có hệ thống, tận dụng thời cơ, chọn thời điểm thích hợp để "ra đòn". Trung Quốc luôn chủ trương "lợi dụng hợp lý, có hiệu quả việc lập pháp trong nước và quốc tế, lấy vũ khí pháp luật để duy trì chủ quyền lãnh thổ và quyền lợi hải dương" [8], vừa đưa ra những ý tưởng hòa bình để trấn an các quốc gia xung quanh, vừa đe dọa bằng sức mạnh (quân sự) [9, tr. 285]. Việc ban hành, giải thích các chính sách pháp luật biển cũng như các hoạt động trên thực địa: dùng vũ lực xâm lược và chiếm đóng phi pháp hai quần đảo Hoàng $\mathrm{Sa}$ và Trường $\mathrm{Sa}$ của Việt $\mathrm{Nam}$; ngang ngược tuyên bố mời thầu và hạ đặt dàn khoan trái phép sâu trong vùng đặc quyền kinh tế và thềm lục địa 200 hải lý của Việt Nam; tuyên bố thành lập cái gọi "thành phố Tam $\mathrm{Sa}$ "; ban hành lệnh cấm đánh bắt hải sản trên Biển Đông; siêu đảo hóa các thực thể ngầm trong hai quần đảo Hoàng $\mathrm{Sa}$ và Truờng $\mathrm{Sa}$ của Việt Nam; cắt phá các rạn san hô và đáy biển, hủy hoại môi truờng biển... Trung Quốc cho thấy quốc gia này không chỉ phớt lờ và vi phạm nghiêm trọng luật pháp quốc tế, mà còn có ý đồ muốn viết lại luật pháp quốc tế để phục vụ cho tham vọng bành trướng, bá quyền của họ.

\section{Sự phi lý trong chính sách, pháp luật biển của Trung Quốc dưới góc độ pháp lý quốc tế}

Trung Quốc, với vị thế là một nước lớn, là ủy viên thường trực của Hội đồng Bảo an của LHQ, là nước thứ 92 phê chuẩn UNCLOS 1982, lẽ ra quốc gia này phải nghiêm chỉnh chấp hành các quy định của luật pháp quốc tế. Tuy nhiên, việc ban hành hàng loạt cách chính sách, pháp luật biển cùng với những hành động hung hăng trên thực địa đã vi phạm nghiêm trọng hầu hết các nguyên tắc cơ bản của luật quốc tế nói chung và UNCLOS 1982 nói riêng, cụ thể như sau:

\subsection{Sự phi lý trong chính sách, pháp luật biển} Trung Quốc dưới góc độ các nguyên tắc co bản của Luật quốc tế

Thứ nhất, Chính sách, pháp luật biển của Trung Quốc đi ngược lại với nguyển tắc bình đẳng chủ quyền quốc gia: Ngày 04/09/1958, Chính phủ nước CHND Trung Hoa ra Tuyên bố về lãnh hải, trong đó khẳng định "lãnh thổ của nước Cộng hòa nhân dân Trung Hoa bao gồm đại lục nước Cộng hòa nhân dân Trung Hoa và các đảo ven biển, Đài Loan và các đảo xung quanh nó bao gồm đảo Điếu Ngư, Bành Hồ, quần đảo Đông $\mathrm{Sa}$, quần đảo Tây $\mathrm{Sa}$, quần đảo Trung $\mathrm{Sa}$, quần đảo $\mathrm{Nam} \mathrm{Sa}$ và tất cả các đảo khác thuộc Trung Quốc". Như vậy, tuyên bố này đã đưa hai quần đảo (vùng đảo) Hoàng $\mathrm{Sa}$ và Trường $\mathrm{Sa}$ (tức Tây $\mathrm{Sa}$ và $\mathrm{Nam}$ Sa theo cách gọi của Trung Quốc) - một trong những bộ phận lãnh thổ thiêng liêng bất khả xâm phạm của Việt Nam vào phạm vi yêu sách của Trung Quốc. Sau đó, trong hai công hàm ${ }^{3}$ CML17/2009 và CML18/2009 ngày 07/05/2009, Điều lệ quản lý trị an biên phòng

\footnotetext{
$\overline{3}$ Permanent Mission of the People's Republic of China the United Nations, Note Verbale No. CML/17/2009 and Note Verbale No. CML/18/2009, Official website of United Nations - Ocean and the Law of the Sea, http://www.un.org/Depts/los/clcs_new/submissions_files/ mysvnm33_09/chn_2009re_mys_vnm_e.pdf; http://www.un.org/Depts/los/clcs_new/submissions_files/v nm37_09/chn_2009re_vnm.pdf, 07/5/2009.
} 
ven biển tỉnh Hải Nam năm $2012^{4}$ [10], Dự thảo sửa đổi Biện pháp thực hiện Luật Ngư nghiệp năm 2013; Báo cáo trình bày lập trường chính thức của CHND Trung Hoa về vụ kiện trọng tài do Philipines khởi xướng ngày 07/12/2014 [11] và các thư ngoại giao trong vụ giàn khoan HD981 năm 2014 và vụ kiện Phi-Trung năm 2016, Trung Quốc cũng trắng trợn tuyên bố "chủ quyền" đối với hai vùng đảo này của Việt Nam. Với việc tuyên bố chủ quyền đối với hai vùng đảo Hoàng $\mathrm{Sa}$ và Trường $\mathrm{Sa}$, Trung Quốc đã xâm phạm nghiêm trọng chủ quyền lãnh thổ của Việt Nam, đi ngược lại với nguyên tắc bình đẳng chủ quyền quốc gia được ghi nhận trong Hiến chương LHQ năm 1945, Tuyên bố ngày 24/10/1970 của Đại hội đồng LHQ, Định ước Hensinki ngày $1 / 8 / 1975$ và nhiều văn kiện pháp lý quốc tế khác.

Thứ hai, chính sách, pháp luật biển của Trung Quốc đã vi phạm nghiêm trọng nguyên tắc "cấm sử dụng vũ lực hoặc đe dọa sử dụng vũ lực trong quan hệ quốc tế": Trong quá trình thực thi các chính sách, pháp luật biển, Trung Quốc đã sử dụng vũ lực cưỡng chiếm trái phép toàn bộ vùng đảo Hoàng $\mathrm{Sa}$ (năm 1956, 1974) và một phần vùng đảo Trường $\mathrm{Sa}$ (năm 1988, 1992, 1995) của Việt Nam. Bên cạnh đó, Trung Quốc còn sử dụng rất nhiều mưu kế, thủ đoạn, chiến thuật, chiến lược trên tất cả các mặt trận kinh tế, chính trị - ngoại giao, gia tăng căng thẳng và không ngừng tạo ra sức ép cho Việt Nam và các quốc gia trong khu vực Biển Đông. Những hành vi nêu trên của Trung Quốc đã cấu thành hành vi đe dọa dùng vũ lực và sử dụng vũ lực đã bị luật pháp quốc tế hiện đại nghiêm cấm.

Thứ $\boldsymbol{b a}$, chính sách, pháp luật biển của Trung Quốc vi phạm nghiêm trọng nguyên tắc hòa bình giải quyết các tranh chẩp quốc tế: Với vị thế là một cường quốc với tiềm lực kinh tế, quân sự khổng lồ, là ủy viên thường trực Hội đồng Bảo an LHQ, lại có công dân là thẩm phán tại hầu khắp các thiết chế tài phán quốc tế,

\footnotetext{
$\overline{4}$ Điều 2 Điều lệ Nam Hải 2012 quy định phạm vi áp dụng là các vùng biển quản hạt và vùng ven biển của tỉnh Hải Nam bao gồm cả "Tây Sa" (Hoàng Sa), "Trung Sa" (trong đó có bãi Hoàng Nham Trung Quốc yêu sách) và "Nam $\mathrm{Sa}$ " (Trường Sa).
}

như: Tòa án Công lý Quốc tế (ICJ), Tòa án Luật Biển Quốc tế (ITLOS), Trọng tài Thường trực Lahaye (PCA)..., lẽ ra Trung Quốc phải tích cực sử dụng các thiết chế này để giải quyết các tranh chấp quốc tế nói chung và tranh chấp Biển Đông nói riêng, tuy nhiên trên thực tế, quốc gia này lại nhất mực khước từ các thiết chế văn minh này ${ }^{5}$. Bên cạnh đó, Trung Quốc cố tình giữ lập trường : "Hoàng Sa không có tranh chấp", "kiên quyết chỉ giải quyết song phương", "không đa phương hóa", "không tài phán hóa" việc giải quyết tranh chấp Biển Đông... mặc dù phía Việt Nam và các quốc gia khác đã nhiều lần đề xuất. Đặc biệt, trong vụ kiện do Philippines khởi xướng tại Tòa trọng tài thành lập theo Phụ lục VII UNCLOS 1982, Trung Quốc còn kiên quyết lập trường "3 không": không chấp nhận thẩm quyền của Tòa, không tham gia tố tụng, không chấp nhận hiệu lực của phán quyết. Trong khi luật pháp quốc tế yêu cầu các quốc gia tích cực sử dụng các biện pháp nhằm giải quyết hòa bình các tranh chấp quốc tế, việc Trung Quốc cố tình trì hoãn, bất hợp tác và cố tình làm trầm trọng thêm tình hình tranh chấp là một trong những biểu hiện tiêu biểu thể hiện sự vi phạm nguyên tắc "hòa bình giải quyết các tranh chấp quốc tế".

Thứ $t u$, chính sách, pháp luật biển của Trung Quốc vi phạm các quy định của nguyên tắc "tận tâm, thiện chí thực hiện các cam kết quốc tế": Trung Quốc với tham vọng "bá chủ toàn cầu", "soán ngôi số một" của Mỹ đã ban hành nhiều chủ trương, chính sách, pháp luật biển phi pháp, đi ngược lại với các cam kết trong những điều ước quốc tế mà quốc gia này là thành viên, vi phạm nguyên tắc Pacta Sunt Servanda:

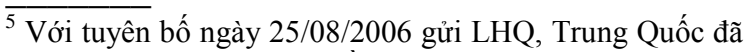
đưa ra các bảo lưu theo Điều 298 của UNCLOS, trong đó loại trừ các tranh liên quan tới danh nghĩa lịch sử và vịnh lịch sử, phân định biển, các hoạt động quân sự và các vụ tranh chấp mà Hội đồng bảo an Liên hợp quốc (trong khi thi hành các chức năng của mình do Hiến chương Liên hợp quốc giao phó) có trách nhiệm giải quyết ra khỏi phạm vi thẩm quyền tài phán của ICJ, ITLOS, Tòa Trọng tài và Tòa Trọng tài đặc biệt được thành lập theo phụ lục VII và phụ lục VIII UNCLOS 1982.
} 
i) Với việc sử dụng vũ lực chiếm đóng trái phép toàn bộ quần đảo Hoàng $\mathrm{Sa}$ và một phần quần đảo Trường $\mathrm{Sa}$ của Việt Nam rồi ngang nhiên tuyên bố chủ quyền trên các quần đảo này; thực hiện các hoạt động gây hấn làm gia tăng căng thẳng ở Biển Đông; không chấp nhận vấn đề "quốc tế hóa Biển Đông"... Trung Quốc đã xé bỏ các cam kết quốc tế, đã vi phạm nghiêm trọng các nguyên tắc cơ bản của luật quốc tế, đặc biệt là nguyên tắc Pacta Sunt Servanda được quy định trong Hiến chương LHQ, Công ước của LHQ về Luật Biển năm 1982 ... mà Trung Quốc là quốc gia thành viên.

ii) Trung Quốc bằng việc hoạch định đường cơ sở quần đảo cho vùng đảo Hoàng $\mathrm{Sa}$; thiết lập một vùng biển 12 hải lý xung quanh các đảo nhân tạo và cấm tàu thuyền, máy bay của các quốc gia khác hoạt động trong vùng biển và vùng trời trên các đảo nhân tạo này; ban hành lệnh cấm đánh bắt cá ở Biển Đông trong mùa cao điểm... đã vi phạm các quy định về hoạch định đường cơ sở; về quy chế pháp lý của các vùng biển; quy chế pháp lý của quần đảo và đảo, các quy định về bảo vệ và giữ gìn môi trường biển được quy định tại các Điều 2-16 (Phần II Lãnh hải và Vùng tiếp giáp), Điều 5574 (Phần V Vùng Đặc quyền kinh tế), Điều 7684, (Phần VI Thềm Lục địa); Điều 46-53 (Phần VI - Các quốc gia quần đảo); Điều 121(Phần VIII- Chế độ các đảo); Điê̂u 194, 197-201 (Phần XII-Bảo vệ và giữ gìn môi trường biển) UNCLOS 1982...

iii) Bằng các chính sách, chiến lược và hành động triển khai trên thực tế làm phức tạp thêm tình hình tranh chấp Biển Đông, cản trở quá trình xây dựng Bộ quy tắc Biển Đông cũng như các hoạt động xâm phạm chủ quyền, quyền chủ quyền và quyền tài phán của Việt Nam và các nước, đe dọa tự do hàng hải và hàng không, hủy hoại nghiêm trọng môi trường biển, đe dọa hòa bình và an ninh trong khu vực và trên thế giới... Trung Quốc đã vi phạm các nghĩa vụ được quy định trong Tuyên bố về quy tắc ứng xử biển Đông - DOC 2002, Bản Quy tắc hướng dẫn thực thi DOC năm 2011, Tuyên bố chung của nước CHND Trung Hoa và Cộng hòa Philippines năm 2000; Thỏa thuận những
Nguyên tắc cơ bản chỉ đạo giải quyết vấn đề trên biển giữa nước Cộng hòa XHCN Việt Nam và nước CHND Trung Hoa năm 2011...

Thứ năm, chính sách, pháp luật biển của Trung Quốc trái với các quy định của nguyên tắc "chiếm hữu thực sự": Theo quy định của luật pháp quốc tế, chủ quyền quốc gia đối với một vùng lãnh thổ phải được xác lập bằng các phương thức thụ đắc hợp pháp trên cơ sở các nguyên tắc nhất định, trong đó có nguyên tắc chiếm hữu thực sự ${ }^{6}$. Trong khi đó, chính sách, pháp luật biển của Trung Quốc ${ }^{7}$ lại hoàn toàn đi ngược với các yêu cầu này, với các biểu hiện cụ thể như sau: i) Hành vi chiếm hữu của Trung Quốc chỉ là các hoạt động mang tính chất tư nhân, không thể hiện ý chí của Nhà nước; ii) Hai vùng đảo Hoàng $\mathrm{Sa}$ và Trường $\mathrm{Sa}$ không phải là lãnh thổ vô chủ hoặc bị bỏ rơi khi Trung Quốc thực hiện việc chiếm hữu; iii) Trung Quốc đã không đưa ra được các bằng chứng nào có sức thuyết phục về việc họ đã thực thi chủ quyền trên hai vùng đảo Hoàng $\mathrm{Sa}$ và Trường Sa một cách liên tục, hòa bình từ khi hai quần đảo này chưa thuộc về Việt Nam; iv) Việc chiếm hữu của Trung Quốc trên hai vùng

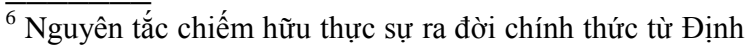
ước Berlin năm 1885 và sau đó được hoàn thiện thông qua tuyên bố Lausanne của Viện Pháp luật quốc tế năm 1888 . Theo nguyên tắc này, việc chiếm hữu lãnh thổ phải đảm bảo tuân thủ các điều kiện sau: $i$ ) Đối tượng chiếm hữu là lãnh thổ vô chủ hoặc lãnh thổ bị bỏ rơi; ii) Chủ thể thực hiện chiếm hữu là Nhà nước, bằng hành động của Nhà nước hoặc nhân danh Nhà nước; iii) Phương pháp chiếm hữu: phải được tiến hành một cách hoà bình, công khai và liên tục trên một vùng lãnh thổ thật sự là vô chủ (res nullius) hoặc bị bỏ rơi (derelicto). Ngoài yếu tố vật chất (corpus), việc chiếm hữu thật sự đồng thời còn đòi hỏi yếu tố tinh thần (animus), nghĩa là ý chí của quốc gia muốn chiếm hữu lãnh thổ đó.

${ }^{7}$ Trong Tuyên bố về lãnh hải của nước CHND Trung Hoa năm 1958; Công hàm $\mathrm{CML} / 17 / 2009$ và $\mathrm{CML} / 18 / 2009$ ngày $07 / 05 / 2009$, Công hàm $\mathrm{CML} / 8 / 2011$ ngày 14/04/2011 của nước CHND Trung Hoa gửi Tổng thư ký LHQ; Báo cáo trình bày lập trường chính thức của CHND Trung Hoa về vụ kiện trọng tài do Philipines khởi xướng ngày $07 / 12 / 2014$; Thư số $\mathrm{A} / 69 / 645$ ngày $10 / 12 / 2014$ của Đại diện thường trực của Trung Quốc tại LHQ gửi Tổng thư ký... Trung Quốc đã khẳng định chủ quyền của mình đối với hai quần đảo Hoàng $\mathrm{Sa}$ và Trường $\mathrm{Sa}$ ở Biển Đông.
} 
đảo Hoàng $\mathrm{Sa}$ và Trường $\mathrm{Sa}$ không đáp ứng được yêu cầu về sự đi kèm của yếu tố tinh thần (animus) và vật chất (corpus) trong chiếm hữu lãnh thố; v) Việc chiếm hữu của Trung Quốc đối với hai vùng đảo Hoàng $\mathrm{Sa}$ và Trường $\mathrm{Sa}$ luôn bị sự phản đối gay gắt của các quốc gia và cộng đồng quốc tế.

\subsection{Sự phi lý trong chính sách, pháp luật biển của Trung Quốc duới góc độ các nguyên tắc đặc thù của Luật biển quốc tế hiện đại}

Không chỉ vi phạm các nguyên tắc cơ bản của luật quốc tế, dưới lăng kính của các nguyên tắc đặc thù của luật biển quốc tế, chính sách, pháp luật biển của Trung Quốc cũng thể hiện rõ sự phi lý, phi pháp, cụ thể như sau:

Thứ nhất, chính sách, pháp luật của Trung Quốc đi ngược lại với nguyên tắc thỏa thuậnmột trong những nguyên tắc đặc thù của Luật biển quốc tế hiện đại: Theo quy định của luật biển quốc tế hiện đại, quốc gia có nghĩa vụ tuân thủ nguyên tắc thỏa thuận, hợp tác với các bên hữu quan để giải quyết các vấn đề pháp lý trong vùng biển chồng lấn. Tuy nhiên, trên thực tế, Trung Quốc lại đơn phương công bố yêu sách "đường lưỡi bò" chiếm khoảng $80 \%$ diện tích Biển Đông, lấn sâu vào các vùng biển thuộc quyền chủ quyền của Việt Nam, Philippines, Brunei, Indonesia, Malaysia mà không hề có sự thỏa thuận với các quốc gia này. Không những vậy, trước thiện chí của các nước mong muốn giải quyết các tranh chấp biển đảo tại các thiết chế quốc tế phổ cập, thì Trung Quốc lại kịch liệt phản đối vấn đề này. Điều này không chỉ được ghi nhận trong các tuyên bố chính thức của giới chức cầm quyền Trung Quốc mà còn được ghi nhận cụ thể trong Báo cáo của Bộ Ngoại giao nước CHND Trung Hoa về Phán quyết ngày 12/7/2016 của Tòa Trọng tài; Sách trắng "Trung Quốc kiên trì thông qua đàm phán giải quyết tranh chấp liên quan giữa Trung Quốc và Philippines ở Nam Hải (Biển Đông)" ngày 01/7/2016 [12].

Thứ hai, chính sách, pháp luật của Trung Quốc đi ngược lại với nguyên tắc công bằng trong phân định biển: Chính sách, pháp luật biển Trung Quốc đã không đảm bảo được một vị thế cân bằng cho các quốc gia trong khu vực với những tuyên bố đơn phương mang tính áp đặt, cưỡng ép đối với các quốc gia trong khu vực Biển Đông. Với việc ban hành các văn bản chính sách, pháp luật thể hiện yêu sách chủ quyền bao phủ khoảng $80 \%$ diện tích Biển Đông, xâm lấn các vùng biển thuộc quyền chủ quyền và quyền tài phán của các quốc gia khu vực, Trung Quốc đã vi phạm nghiêm trọng nguyên tắc công bằng ${ }^{8}[13$, tr. 15$]$ dù công bằng chỉ mang ý nghĩa tương đối. Yêu sách này được vạch ra không dựa trên bất kỳ phương pháp hoạch định, phân định biển nào và cũng không được công bố theo thủ tục luật định bằng hải đồ với bản kê tọa độ địa lý rõ ràng và nộp Liên hợp quốc lưu chiểu. Hơn nữa, vừa công khai quốc tế bản đồ đường yêu sách, Trung Quốc vấp phải sự phản đối kịch liệt từ phía các quốc gia hữu quan cũng như các quốc gia trong và ngoài khu vực, bởi sự phi lý của đường yêu sách.

Thứ ba, chính sách, pháp luật biển của Trung Quốc đi ngược lại với nguyên tắc "bảo vệ môi trường biển", "bảo vệ và khai thác hợp lý các nguồn tài nguyên trên biển": Từ khoảng cuối những năm 2013, đầu năm 2014 đến nay, Trung Quốc đã tiến hành hàng loạt các hoạt động lấn biển, nạo vét, san lấp và cải tạo với quy mô lớn đồng loạt trên nhiều thực thể do quốc gia này chiếm đóng trên Biển Đông mà chưa có dấu hiệu giảm tốc [14]. Hành vi "đảo hóa" của Trung Quốc đã và đang tàn phá nhiều rạn san hô (khoảng 80\% theo nhận định của giới nghiên cứu Trung Quốc) [15], hủy hoại nghiêm trọng môi trường, làm mất cân bằng sinh thái Biển Đông, hủy diệt các loài sinh vật biển, triệt phá nguồn sinh kế duy nhất của hàng chục triệu ngư dân (chưa kể những tổn thất không thể tính bằng tiền và không thể khôi phục), vi phạm nghiêm trọng nguyên tắc "bảo vệ môi trường biển", "bảo vệ và khai thác hợp

\footnotetext{
${ }^{8}$ Theo một số tính toán sơ bộ, “đường lưỡi bò" của Trung Quốc đã "lấn chiếm" nhiều vùng biển của Việt Nam và các quốc gia trong khu vực với diện tích cụ thể như sau: Việt Nam 1.170.000 km², Philippines $620.000 \mathrm{~km}^{2}$, Malaysia $170.000 \mathrm{~km}^{2}$, Brunei $50.000 \mathrm{~km}^{2}$ và Indonesia $35.000 \mathrm{~km}^{2}$.
} 
lý các nguồn tài nguyên thiên nhiên biển" và đi ngược lại với xu hướng của khu vực về bảo vệ môi trường biển, bảo vệ quyền con người.

Thứ tur, chính sách, pháp luật biển của Trung Quốc xâm phạm nguyên tắc "tự do biển cả" và "sử dụng biển cả vì mục đích hòa bình": Thông qua việc yêu sách khoảng $80 \%$ diện tích Biển Đông, phạm vi yêu sách của Trung Quốc không chỉ giới hạn ở các vùng biển đảo thuộc chủ quyền, quyền chủ quyền và quyền tài phán của các quốc gia trong khu vực mà còn bao gồm cả khu vực Biển cả và Vùng. Trong khi đó, theo quy định của UNCLOS 1982, Biển cả và Vùng là di sản chung của nhân loại. Việc Trung Quốc thiết lập quyền kiểm soát với khu vực này, thực hiện hàng loạt các hoạt động gây hấn trên biển như cắt cáp, đâm va, bắt giữ trái phép tàu và ngư cụ của ngư dân, triển khai rầm rộ hoạt động "siêu đảo hóa" phi pháp tại các thực thể ngầm... đã vi phạm nghiêm trọng nguyên tắc "tự do biển cả" và "sử dụng biển cả vì mục đích hòa bình" được ghi nhận tại Điều 87 và 88 UNCLOS 1982.

\subsection{Sự phi lý trong chính sách, pháp luật biển của Trung Quốc duới góc độ các quy định của UNCLOS 1982}

Được ký kết ngày 30/4/1982 và thông qua ngày 10/12/1982 tại Môntêgobay (Jamaica), với 320 điều khoản, 17 phần và 9 phụ lục, UNCLOS 1982 đã tạo ra cơ sở pháp lý quan trọng để các quốc gia xác lập chủ quyền, quyền chủ quyền và quyền tài phán đối với các vùng biển. Vận dụng các quy định của UNCLOS 1982 vào phân tích, đánh giá hệ thống chính sách, pháp luật biển của Trung Quốc, có thể thấy tồn tại một số vấn đề bất cập như sau:

Thứ $n h a \hat{t}$, quy chế pháp lý của đảo và quần đảo theo quy định của pháp luật Trung Quốc không phù hợp với các chuẩn tắc quốc tế chung: Theo quan điểm của Trung Quốc, Hoàng $\mathrm{Sa}$ và Trường $\mathrm{Sa}$ là quần đảo và được hưởng đầy đủ quy chế pháp lý được quy định tại Điều 121 UNCLOS 1982. Quan điểm này được thể hiện cụ thể thông qua phương pháp vạch đường cơ sở quần đảo cho vùng đảo
Hoàng Sa trong Tuyên bố về đường cơ sở tính chiều rộng lãnh hải CHND Trung Hoa năm 1996 và tuyên bố "quần đảo Nam Sa (tức Trường Sa) được hướng đầy đủ Lãnh hải, Vùng đặc quyền kinh tế (EEZ) và Thềm luc địa" ${ }^{9}$ [16] được khẳng định trong Công hàm $\mathrm{CML} / 8 / 2011$ ngày 14/04/2011 và "Báo cáo trình bày lập trường chính thức của Cộng hòa Nhân dân Trung Hoa về vụ kiện trọng tài do Philippines khởi xướng" ngày 07/12/2014 [17]. Trong khi đó, theo quy định tại Điều 121 UNCLOS 1982 , để được coi là đảo thì cấu tạo địa chất đó phải đáp ứng được các điều kiện đó là "một vùng đất tự nhiên", "có nước bao bọc", "ở trên mặt nước khi thủy triều lên"; và, để được hưởng đầy đủ nội thủy, lãnh hải, vùng tiếp giáp, vùng đặc quyền kinh tế và thềm lục địa thì đảo đó phải đáp ứng được điều kiện là "thích hợp cho con người đến ở hoặc cho một đời sống kinh tế riêng". Xem xét về đặc điểm tự nhiên và cấu tạo địa chất, địa mạo hai vùng đảo Hoàng $S a$ và Trường $\mathrm{Sa}$ có thể thấy: Hai vùng đảo Hoàng $\mathrm{Sa}$ và Trường $\mathrm{Sa}$ nằm ở khu vực trung tâm $\mathrm{Biển}$ Đông, phần lớn là những bãi cát không thể trồng trọt; vào khoảng một chục đảo khác là do những mỏm đá tạo thành. Trong vùng đảo Hoàng $\mathrm{Sa}$ chỉ có 8 hòn đảo là luôn nổi trên mặt nước lúc thủy triều lên [18]. Còn vùng đảo Trường $\mathrm{Sa}$ có từ 25 đến 35 vị trí (trong tổng số khoảng 80 đến 90 vị trí) nằm trên mặt nước biển lúc thủy triều lên cao ${ }^{10}$. Theo đánh giá của Cố vấn pháp luật của Bộ Ngoại giao Philippines

\footnotetext{
${ }^{9}$ Nguyên văn: "Nansha Island is fully entitled to Teritorial Sea, Exclusive Economic Zone (EEZ) and Continential Shelf'.

${ }^{10}$ Riêng đối với vùng đảo Trường Sa các nhà nghiên cứu có những đánh giá khác nhau do có sự không nhất trí về việc tính một số vị trí là một hay hai cấu trúc, và về việc coi những vị trí nào là nằm trên mặt nước biển khi thủy triều lên cao một cách tự nhiên. Một số vị trí thay đổi do bão hay được bồi dần lên. Brice $\mathrm{M}$. Clagett lại cho rằng có khoảng 26 vị trí. Một báo cáo gần đây của David Hancox và Victor Prescott tiêu đề "Mô tả vi trí địa lý của quần đảo Trưòng Sa và báo cáo thăm dò biển ở nhũng đảo này", tính được 28 vị trí - nghiên cứu này đã được Phòng phân tích bản đồ và ranh giới thuộc Bộ Ngoại giao Mỹ sử dụng trong bản đồ biển Nam Trung Hoa mà họ phát hành tháng 5/1995. Ji Guoxing trong cuốn "Nhũng tranh chấp trong quần đảo Truòng Sa và triển vọng giải quyết" đã tuyên bố có 25 vị trí trong quần đảo nằm trên mặt nước biển.
} 
[19, tr. 117-120] và các nhà nghiên cứu khác (như Gerardo M.C. Valero [20, tr. 314-315], Michael Bennett), cũng cho thấy các đảo thuộc quần đảo Hoàng $\mathrm{Sa}$ và Trường $\mathrm{Sa}$ không đáp ứng được điều kiện mà Điều 121 UNCLOS 1982 quy định. Hai vùng đảo này hầu như bao gồm các đảo đá, nằm ở khu vực trung tâm Biển Đông, mỗi đảo có diện tích rất nhỏ (đảo lớn nhất Ba Bình rộng khoảng 1,2 km2, đảo Phú Lâm rộng khoảng $1,5 \mathrm{~km} 2$ ), cằn cỗi, thời tiết khắc nghiệt bão tố nhiều, không thích hợp cho con người đến ở và cho một đời sống kinh tế riêng [21] nên xung quanh các đảo này chỉ có thể có nội thủy và lãnh hải mà thôi, không có vùng đặc quyền kinh tế và thềm lục địa (theo khoản 3 Điều 121 UNCLOS 1982). [22, tr. 160] Do đó, việc Trung Quốc tuyên bố hai vùng đảo này có đầy đủ vùng đặc quyền kinh tế và thềm lục địa là hoàn toàn trái với các quy định của UNCLOS 1982.

Thư hai, việc vạch đường cơ sở của Trung Quốc đi ngược lại các quy định của UNCLOS 1982 về đường cơ sở thẳng và đường cơ sở quần đảo: Trong Tuyên bố về đường cơ sở tính chiều rộng lãnh hải năm 1996, Trung Quốc đã công bố hệ thống các điểm cơ sở của quần đảo Hoàng Sa (của Việt Nam). Qua hệ thống các điểm cơ sở được công bô, có thể thấy Trung Quốc đã vạch đường cơ sở thẳng nối liền các điểm ngoài cùng của các đảo xa nhất và các bãi đá của quần đảo tương tự như cách vạch đường cơ sở quần đảo của quốc gia quần đảo quy định tại Điều 47 phần IV UNCLOS 1982. Tuy nhiên, diện tích mà hệ đường cơ sở này của Trung Quốc bao lấy là một khu vực rộng $17.000 \mathrm{~km}^{2}$, trong khi tổng diện tích các đảo nổi của quần đảo Hoàng Sa chỉ khoảng $10 \mathrm{~km}^{2}$, không phù hợp tỷ lệ giữa khoảng $1: 1$ và $9: 1$. Ngoài ra, hầu hết các đá, bãi san hô mà Trung Quốc sử dụng ở đây đều không thích hợp cho con người đến ở hoặc không có một đời sống kinh tế riêng. Các đảo này lại cách xa nhau quá 24 hải lý, không có lý do gì có thể nối các đoạn đường cơ sở như vậy. Do vậy bất kỳ một vùng biển nào mà Trung Quốc tuyên bố bao quanh vùng biển của các mỏm đá, bãi san hô này về mặt kỹ thuật đều trái với các quy định của UNCLOS 1982.
Trung Quốc không phải là một quốc gia quần đảo nên việc xác định đường cơ sở của quần đảo Hoàng Sa theo như trong Tuyên bố năm 1996 của nước này là chưa phù hợp với quy định của luật pháp và thực tiễn quốc tế.

Thứ ba, quy chế pháp lý của các vùng biển theo quy định của pháp luật Trung Quốc về biển đảo không phù hợp với các chuẩn tắc được quy định trong UNCLOS 1982

i) Sự phi lý trong các quy định liên quan đến quy chế pháp lý của lãnh hải: UNCLOS 1982 ghi nhận quyền đi qua không gây hại trong lãnh hải cho tàu thuyền nước ngoài (Điều 17) mà không bị cản trở hay hạn chế (Điều 24). Tuy nhiên, với quy định "tàu thuyền quân sự nước ngoài vào lãnh hải nước Cộng hòa nhân nhân Trung Hoa phải được sự phê chuẩn của Chính phủ nước CHND Trung Hoa" tại Điều 6, Luật lãnh hải và vùng tiếp giáp năm 1992, Trung Quốc đã hạn chế phạm vi đối tượng được hưởng quyền đi qua không gây hại theo quy định của UNCLOS 1982, xâm phạm nghiêm trọng các quy định của pháp luật quốc tế về quy chế pháp lý của lãnh hải.

ii) Sự phi lý trong các quy định liên quan đến quy chế pháp lý của vùng đặc quyền kinh tế và thềm lục địa: Trung Quốc thông qua các việc ban hành Luật Ngư nghiệp năm 1986 (sửa đổi năm 2000); Luật Tài nguyên khoáng sản năm 1986, Điều lệ quản lý trị an biên phòng ven biển tỉnh Hải Nam năm 2012; Dự thảo sửa đổi biện pháp thực hiện Luật Ngư nghiệp năm 2013... nhằm quản lý, kiểm soát tài nguyên biển, can thiệp vào hoạt động trong vùng đặc quyền kinh tế và thềm lục địa của các quốc gia, đã vi phạm nghiêm trọng các quy định của UNCLOS 1982 về việc thăm dò, khai thác, quản lý và bảo tồn tài nguyên biển, quyền tự do hàng hải, tự do hàng không, tự do lắp đặt dây cáp và ống dẫn ngầm của các quốc gia trong vùng đặc quyền kinh tế và thềm lục địa. Đặc biệt, với quy định tại Điều 14, Luật vùng đặc quyền kinh tế và thềm lục địa năm 1998, Trung Quốc đã đề cao "quyền lợi mang tính lịch sử của nước CHND Trung Hoa" cao hơn cả quy định của luật và thực tiễn quốc tế, tạo cơ sở 
pháp lý cho việc hiện thực hóa các yêu sách bành trướng và phi pháp của mình.

Thứ tư, chính sách, pháp luật về khai thác tài nguyên thiên nhiên trên biển của Trung Quốc đã xâm phạm nghiêm trọng quyền thực thi chủ quyền, quyền chủ quyền và quyền tài phán của các quốc gia trong khu vực Biển Đông: Bằng việc ban hành lệnh cấm đánh bắt cá hàng năm ở Biển Đông vào mùa cao điểm từ năm 1999 đến nay, quy định nghĩa vụ phải xin phép cho tàu thuyền nước ngoài và quyền xua đuổi, tịch thu tài sản, xử phạt hành chính và quyền truy tố đối với tàu thuyển và thủ thủ đoàn nước ngoài tại vùng biển chiếm $2 / 3$ Biển Đông - nơi thuộc vùng đặc quyền kinh tế và thềm lục địa của Việt Nam và một số nước ASEAN trong Điều lệ quản lý trị an biên phòng ven biển tỉnh Hải Nam, có hiệu lực từ ngày 1/1/2013; Dự thảo sửa đổi Biện pháp thực hiện Luật Ngư nghiệp nước CHND Trung Hoa, có hiệu lực từ 1/1/2014, Trung Quốc đã xâm phạm nghiêm trọng đến việc thực thi chủ quyền chủ quyền và quyền tài của Việt Nam và các quốc gia khu vực Biển Đông, trong đó trực tiếp nhất đó là quyền của quốc gia ven biển đối với việc khai thác tài nguyên sinh vật được ghi nhận trong điểm $\mathrm{a}$, khoản 1 , Điều 56 và quyền tự do hàng hải của quốc gia ven biển được quy định tại điểm a, khoản 1, Điều 87 UNCLOS 1982.

Thứ năm, chính sách "đảo hóa", "siêu đảo hóa" của Trung Quốc ở Biển Đông xâm phạm nghiêm trọng các quy định về bảo vệ môi trường biển, về quy chế pháp lý của các đảo nhân tạo, thiết bị công trình trên biển được quy định trong UNCLOS 1982: Với hàng loạt các hoạt động nạo vét, cải tạo các thực thể ngầm ở quần đảo Trường Sa, Trung Quốc đã vi phạm nghiêm trọng nghĩa vụ đánh giá tác động môi trường biển theo quy định tại Điều 14, nghĩa vụ hợp tác trong bảo vệ môi trường, được quy định tại Điều 197-201, nghĩa vụ bảo vệ môi trường biển theo quy định tại Điều 192-196, Điều 207298 UNCLOS 1982. Các hoạt động này còn trái với tinh thần của nguyên tắc 2 trong Tuyên bố Stockholm năm 1972 của Hội nghị LHQ về môi trường con người, cũng như không phù hợp với nguyên tắc 7 của Tuyên bố Rio De Janeiro năm
1992 về môi trường và phát triển, vi phạm Công ước về đa dạng sinh học, Công ước về bảo vệ các loài động, thực vật hoang dã nguy cấp và Nghị quyết của các Hội nghị môi trường thế giới... Ngoài ra, với tuyên bố cấm tàu thuyền và các phương tiện bay nước ngoài được quyền đi vào phạm vi 12 hải lý xung quanh các đảo nhân tạo, Trung Quốc đã vi phạm nghiêm trọng các quy định về khu vực an toàn của thiết bị, công trình nhân tạo trên biển theo Điều 60 và Điều 80 UNLCOS 1982.

Thứ sáu, một số sự vi phạm khác: Thông qua hàng loạt các hành động như cắt cáp tàu Bình Minh và tàu Viking II của Việt Nam (năm 2011-2012), chủ động đâm va, sử dụng trực thăng và vòi rồng để ngăn cản các tàu Việt Nam (vụ giàn khoan HD 981 năm 2014); gây hấn với tàu Phillippines; cản trở hoạt động tìm kiếm cứu nạn trên biển của Việt Nam; không cho ngư dân Việt Nam trú bão (2016)... Trung Quốc đã xâm phạm nghiêm trọng các quy định về an toàn hàng hải (tại Điều 94 UNCLOS 1982 và Công ước quốc tế về phòng ngừa đâm va trên biển 1972), về nghĩa vụ giúp đỡ (Điều 98 UNCLOS 1982 và Công ước quốc tế về Tìm kiếm cứu nạn và an toàn hàng hải năm 1974), về quyền con người trong các công ước quốc tế về quyền con người năm 1948, 1996...

\section{Kết luận}

Trung Quốc, với vị thế địa chính trị, là cường quốc nhất nhì thế giới, với sự lớn mạnh không ngừng trên tất cả các lĩnh vực kinh tế, văn hóa, chính trị- ngoại giao, quốc phòng an ninh, đã ban hành rất nhiều chính sách, pháp luật về biển đảo nhằm khẳng định cho vị thế siểu cường thế giới cũng như tham vọng độc chiếm Biển Đông của mình. Quá trình xây dựng, thực thi chính sách, pháp luật biển của Trung Quốc gần 70 năm qua, kể từ năm 1949, đã phản ánh rõ nét âm mưu, tham vọng và chiến lược tiến ra biển và từng bước thống trị Biển Đông và các đại dương thế giới. Nội dung xuyên suốt trong chính sách, pháp luật biển của Trung Quốc là tư tưởng bá quyền và chủ nghĩa 
"Đại Hán", thể hiện tham vọng bành trướng trên biển, biến Trung Quốc trở thành "cường quốc số một" của thế giới. Mặc dù tìm mọi cách để né tránh hoặc loại bỏ những quy định có thể gây bất lợi, sử dụng "tiêu chuẩn kép" "làm xiếc ngôn từ", cắt dán, ngụy tạo, xuyên tạc, viện dẫn sai lệch, đổi trắng thay đen, tung hỏa mù, đưa ra những quy định không giống ai; với những hành động ngang ngược trên Biển Đông; đồng thời đã tận dụng triệt để những quy định của pháp luật quốc tế có lợi cho mình, song Trung Quốc không thể nào che đậy được sự vi phạm nghiêm trọng luật pháp quốc tế của Trung Quốc cũng như sự vô trách nhiệm của quốc gia này trước cộng đồng quốc tế.

\section{Lời cảm ơn}

Bài viết này được thực hiện trong khuôn khổ Đề tài cấp Đại học Quốc gia Hà Nội, mã số QG.16.64, "Những nội dung trái pháp luật quốc tế trong chính sách, pháp luật biển của Trung Quốc trên Biển Đông”, từ năm 2016 đến năm 2017, do GS. TS. GVCC. Nguyễn Bá Diến chủ nhiệm.

\section{Tài liệu tham khảo}

[1] Tôn Trung Sơn, Toàn tập, quyển 6, Bắc Kinh, NXB Sách Trung Hoa, 1985.

[2] Nhiều tác giả, Xung đột trên Biển Đông không còn là nguy cơ tiềm ần, NXB Tri thức, Hà Nội, 2012.

[3] Nguyễn Hải Hoành, "Trung Quốc: Chiến lược trở thành cường quốc biển”, Tạp chí Nghiên cứu Quốc

[http://nghiencuuquocte.org/215/03/17/trungquoc-chien-luoc-cuong-quoc-bien/], 17/03/2015.

[4] Nguyễn Bá Diến, Yêu sách “đường lưỡi bò" phi lý của Trung Quốc và chủ quyền của Việt Nam trên Biển Đông, Sách chuyên khảo, NXB Thông tin và Truyền thông, Hà Nội, 2015.

[5] Xu Qi (2004), Maritime Geostrategy and Development of The Chinese Navy in the early twenty-first century, Translated by Andrew S. Erickson and Lyle J.Goldstein, Naval War College Review, Autumn 2006, Vol. 59, No. 4.
[6] 海洋法展展略研究所 (Viện hàng hải Trung Quốc)（2010)，“中国海洋发展报告2010内容简 介”(Giới thiệu về "Báo cáo phát triển đại dương của Trung Quốc năm 2010”), 海洋法展展略研究所, http://www.cima.gov.cn/_ d270570118.htm

[7] Huỳnh Tâm Sáng, Biển Đông trong chiến lược trở thành cường quốc biển của Trung Quốc, Khóa luận tốt nghiệp Khoa Quan hệ quốc tế, trường Đại học KHXH \&NC thành phố Hồ Chí Minh.

[8] Bộ Ngoại giao CHND Trung Hoa, International Recognition of China's Sovereignty over the Nansha Islands, Lưu trữ bởi WebCite ${ }^{\circledR}$ tại [http://www.fmprc.gov.cn/mfa_eng/, 17/11/2000].

[9] Lê Văn Mỹ (chủ biên), Ngoại giao Cộng hòa Nhân dân Trung Hoa hai mươi năm đầu thế kỷ XXI, NXB Khoa học Xã hội, Hà Nội, 2007.

[10] Ủy ban Thường vụ Quốc vụ viện - Hội đồng nhân dân tỉnh Hải Nam, Điều lệ quản lý trị an biên phòng ven biển tỉnh Hải Nam ngày 31/12/2012, có hiệu lực từ ngày 01/01/2013 [http://www.hq.xinhuanet.com/news/2013-01/01c_114221654.htm].

[11] Position Paper of the Government of the People's Republic of China on the Matter of Jurisdiction in the South China Sea Arbitration Initiated by the Republic of the Philippines, 7 December 2014, [http://en.nanhai.org.cn/uploads/file/file/zcaen.pdf].

[12] Ministry of Foreign Affairs, the People's Republic of China, China Adheres to the Position of Settling Through Negotiation the Relevant Disputes Between China and the Philippines in the South China Sea, 2016/07/13, [http://www.fmprc.gov.cn/mfa_eng/zxxx_662805/ t1380615.shtml].

[13] Peter Kien - Hong Vu, "Đường chũ̃ U (đứt khúc) của Trung Quốc (Việt Nam gọi 1à đường lưỡi bò) trên Biển Đông: Các điểm, đường và khu vực", Tạp chí Thời đại mới, số 15 , tháng 3/2009.

[14] Dương Danh Huy, Việc Trung Quốc xây đảo ồ ạt và UNCLOS, Trang Nghiên cứu Biển Đông - Học viện Ngoại giao Việt Nam: [http://nghiencuubiendong.vn/nghien-cuuvietnam/5030-viec-trung-quoc-xay-dao-o-at-vaunclos], 22/06/2015.

[15] Hữu Hoàng, Học giả tố cáo Trung Quốc hủy hoại môi trường sinh thái Biển Đông, [http://www.vietnamplus.vn/hoc-gia-to-cao-trungquoc-huy-hoai-moi-truong-sinh-thai-biendong/384371], Vietnamplus, 04/05/2016. 
[16] Permanent Mission of the People's Republic of China to the United Nations, Note Verbale No. CML/8/2011, Official website of United Nations - Ocean and the Law of the Sea, [http://www.un.org/Depts/los/clcs_new/submissio ns_files/vnm37_09/chn_2011_re_phl_e.pdf], 14/4/2011.

[17] People's Republic of China, "Position Paper of the Government of the People's Republic of China on the Matter of Jurisdiction in the South China Sea Arbitration Initiated by the Republic of the Philippines," 7 December 2014 [http://en.nanhai.org.cn/uploads/file/file/zcaen.pdf].

[18] Monique Chemillier - Gendreau (1998), Chủ quyền trên hai quần đảo Hoàng $\mathrm{Sa}$ và Trường $\mathrm{Sa}$, NXB Chính trị Quốc gia, Hà Nội.
[19] Coquia J.R, "Những vấn đề ranh giới ở Biển Đông", Tạp chí Luật - Trường Đại học Bristish Colombia, 1990.

[20] Gerardo M.C. Valero, "Những tranh chấp ở quần đảo Trường Sa", 18 Marine Policy, 314 - 315 (1994).

[21] Brice M.Clayet, Những yêu sách đối kháng của Việt Nam và Trung Quốc ở khu vực bãi ngầm Tư Chính và Thanh Long trong Biển Đông, NXB Chính trị Quốc gia, Hà Nội, 1996.

[22] Nguyễn Bá Diến, "Quy chế pháp lý quốc tế chung về biển, đảo và những vấn đề cần áp dụng đối với Hoàng $\mathrm{Sa}$, Trường Sa", Tạp chí Khoa học Luật học, tập 25, số 3, 2009.

\title{
More Discussion on the Contrary of China's Marine Policies and Legislation to International Law - in View of the Fundamental Principles and the 1982 United Nations Convention on the Law of the Sea
}

\author{
Nguyen Ba Dien, Dong Thi Kim Thoa \\ VNU School of Law, 144 Xuan Thuy, Cau Giay, Hanoi, Vietnam
}

\begin{abstract}
This article provides an overview on characteristics of China's marine policies and legislation. Thereby, the article brings out the contrary of China's marine policies and legislation to international law in view of the fundamental principles of the international law as well as the international law of the sea, stipulated in the 1982 United Nations Convention on the Law of the Sea. The article comes to the conclusion that the overall content of China's marine policies and legislation reflects the hegemonism and thinking of "Great China", presenting the ambition of marine expansion. Despite using various cheating skills, China cannot conceal the contrary in its marine policies and legislation to the international law as well as its irresponsibility towards the international community.
\end{abstract}

Keywords: Contrary to international law, China's marine policies, China's marine legislation, international law, fundamental principles, Law of the Sea 